\title{
Plural Form of Polish Madness \\ Side Notes to Mira Marcinów's The History of Polish Madness. Vol. 1. The Study of Melancholy
}

\author{
Szymon Wróbel \\ Institute of Philosophy and Sociology of Polish Academy of Sciences \\ Faculty of Artes Liberales, University of Warsaw, Poland \\ wrobelsz@gmail.com
}

Received 11 August 2018; accepted 30 January 2019; published 9 Decemeber 2019

\begin{abstract}
The task of the paper is two-fold. The author is reading Mira Marcinów's book upon recognition of its importance in two debates; that on the subject of madness and its conditions, and that on Poland and its character, i.e. the specificity of Polish melancholy. The author is reading the book to reflect upon the status of melancholy in culture and its unique position. In this endeavour, author attempt to recognize the structure of the melancholic subject and its problematics. Above all, he wonder whether the melancholic has no doubts about his life. A fairly justified hypothesis would be that the melancholic sees himself as a dead rather than a living body.
\end{abstract}

Keywords: allegory; genealogy; history; language; life; madness; melancholy; power; subject.

\section{History and Histories}

It was in the famous essay On the Concept of History where Walter Benjamin rendered „empathizing" - a process of empathy - an invalid method of historical materialism. Its origin is acedia, ,the indolence of the heart," which, in failing to grasp and hold the genuine historical image that flares up briefly at the very moment of its obliteration, takes for its image what is given, that is, what has survived (Benjamin, 2005). Benjamin asks a simple question: with whom the adherents of historicism actually empathize as they reconstruct the facts? The answer is scandalous for historians as it passes irrevocable judgment: it is with the victors and victors only. In the history of madness the „victor” is „medicine" with its complex diagnostics, while the „victim” is the madman himself with his naked and simple life. 
Benjamin, persistently discontented, adds:

There is no document of culture which is not at the same time a document of barbarism. [...] The historical materialist therefore dissociates himself from this process of transmission as far as possible. He regards it as his task to brush history against the grain. (Benjamin, 2005, p. 392)

It is, therefore, compelling a task to address the question whether The History of Polish Madness, intimidating and highly commendable in many regards, indeed brushes history against the grain (Marcinów, 2018). Conformist reading is like hand-sanding along the grain, merely producing a smooth finish, a gesture cancelling time, an open signal to the world that nothing has happened. Reading against the grain, however, is akin to raising the alarm. It would do justice to madness to know whether Mira Marcinów, in writing the history of nineteenth-century reverie in Poland, empathizes with the Polish madness, and if that were so, with whom does the author empathize? One should likewise wish to know, whether there is one concept or one affect in grasping the enormity of Polish madness? Is there at our disposal a fixed concept of melancholy?

In my remarks about the book The History of Polish Madness I am trying to elucidate the Polish thread. What I am asking about is the specificity of Polish madness. If madness is always constructed and fabricated, if madness is „transactional reality” or „temporary mental illness," then, what is the specifics of the fabrication of Polish madness, the Polish transactional reality? Why the path of Polish madness begins from and is paved by melancholy, „gloominess,” „stuffiness,” „Polish hyper-spirituality”? Why is Polish reality „gloomy” and not „cheerful,” for example? Does the Polish discourse on this ,gloominess" bring something new to the global discourse? What kind of gallery or archive of cases of „reverie people” does the author present us with? What is it that they are mulling over so much? Are these men or women? Do we know anything about their sorrows and personal stories? How does the author want to convince us that the characters present therein are real? What does the nineteenth century constitute for the author? It would well seem it is a kind of „optics” rather than a classic ,epoch.” The author repeatedly remarks that she is not a historian. Who then is Mira Marcinów in this book - an archaeologist, a genealogist, or, perhaps, a therapist? Is the history of melancholia in Poland a history of social emotiveness or rather a pious history of the idea of disease? Let me ask again: why does the author begin with melancholia instead of psychosis or hysteria - which the author heralds to be dealt with in the future - or even not stupidity, understood as the absence of reason, which the author makes no reference to and probably does not even recognize?

Friedrich Nietzsche claimed that history belongs to the living person in three respects. It belongs to him as an active and striving person; it belongs to him as a person who preserves and admires; it belongs to him as a suffering person in need of emancipation. This trinity of relationships corresponds to a trinity of methods for history, to the extent that one may make the distinctions, a monumental method, an antiquarian method, and a critical method (Nietzsche, 1878/1995). In this context, we must ask the question what kind of history is the Mira Marcinów's history of Polish madness? 
The task I set before myself in this text is therefore two-fold. I am reading Mira Marcinów's book upon recognition of its importance in two ongoing debates; that on the subject of madness and its conditions, and that on Poland and its character, i.e. the specificity of Polish melancholy. Here, I am not merely inspecting the work of the author. In my reading, apart from reconstructive motives and the sole desire to read, I dare to feed my speculative will, the will to reflect upon the status of melancholy in culture and its unique position. In this endeavour, I attempt to recognize the structure of the melancholic subject and its problematics. Above all, however, I wonder whether-by any chance - the melancholic indeed has no doubts about his life. A fairly justified hypothesis would be that the melancholic sees himself as a dead rather than a living body.

\section{Three Sets: Author's Voice, Mad Images and Learned Words}

At first glance, the book consists of three separate parts - the author's lecture on the Polish ship of fools, an anthology of native psychological and medical magazines, and a fairly eclectic album of photos and engravings on the theme of madness. We have, then, the author's own text, the original texts of Polish psychiatrists of the nineteenth century, and images scattered in time, from the famous photography of Foucault and Sartre demonstrating on the streets of Paris in 1972 and the photographs of anti-psychiatric demonstrations, through advertisements of various drugs, to Wojciech Weiss' painting The Melancholic and The Consumptive, and a cadre from the 2017 movie Pieniadze albo życie... zaczyna sie jutro („Money or Life ... Begins Tomorrow”) directed by Dziadkiewicz and Śmiałek. It begs the question what connects the words of Mira Marcinów, dusty words of doctors and those eclectic images of madness, more often than not—of non-Polish origin? Well, all three elements find a common denominator in one research purpose: to account for the birth of the Polish psychological thought and to depict the birth of Polish melancholy. Perhaps Polish madness can only be framed and described from the outside, with nonPolish reason. This should not be ruled out as a hypothesis.

The problem, however, is that there is no such moment of „birth.” There is no such moment to account for the birth of madness. Foucault and Derrida had already discussed this in the context of the History of Madness in the Classical Age (Foucault, 1965; Derrida, 1978; Foucault, 1997). Similarly, let us not make mistake, there is no and will be no moment to account for the birth of hysteria and psychosis - two other grand themes announced as the following volumes of Mira Marcinów's writing. According to Georges Didi-Huberman what is at our disposal is a moment when hysteria was photographed in a Paris hospital in Salpêtrière, which marks the beginning of the iconography of hysteria (Didi-Huberman, 2003). Hysteria, however, always remains in images and in the service of images. Melancholy always remains in allegory and in the service of allegory. Melancholic dies because it is the only way to get a place in an allegory. The life of a melancholic turns out to be a life for a corpse, the body dies to become a corpse. 
It can be argued that the above a manner of writing renders a certain judgment about what melancholy is and what is its axial symptom. Placing the melancholic in the frame without life, I suggest that melancholy is unable to live, or, that it lacks the will to live. Lack of the will to live ensues, above all, the inability to love and making affective investment in the objects of the surrounding world. In fact, Freud - already in his famous Mourning and Melancholia - warned us that melancholy is a ,wavering concept," especially in descriptive psychiatry, because it occurs in various clinical constellations, the reduction of which to the common denominator never seems certain. The same Freud, in the same text, however, decides in favour of such a concept of melancholy in which the key symptom is the loss of ability to find a new object of love (Freud, 1917, pp. 237-258). The melancholic becomes dead in life. He is not so much in doubt as to whether he is dead or alive, but, rather, holds a simple conviction that he is dead.

Freud in the cited text also adds that, for the melancholic, what becomes poor and empty is not so much the world as it is the Self. The subject of melancholy appears to be empty, a shell of an egg devoid of life. The author of Mourning and Melancholia adds, saving no one and writing from the level of his clinical realism, that by subjecting itself to increased and ruthless self-criticism, the melancholic may actually be close to self-knowledge. In doing so-Freud posits, the melancholic nears learning the truth about humanity. Hamlet is for Freud a paradigmatic figure of the melancholic who, having lost the object of love, experiences the simultaneous destruction of his Self. Melancholic in the clinic is the result of consistent criticism. It is this criticism of the world and of himself which deprives him of the will to be in the world and to be himself, and therefore condemns the melancholic subject to clinical existence. We should therefore not refrain from asking an awkward question: why does one need to develop illness to reach the truth about oneself?

Well, the simplest answer to these questions would be a sober one and harsh: one has to develop illness because the subject of health is not the subject of the truth on his own subject. The subject of health is not a subject of truth on itself. The subject of health is not a subject of truth due to the necessity to maintain itself in a state of health forcing it to constantly produce ,good” and „untrue” fantasies about itself. These fantasies are idealizations. The will of life is the will to deceive oneself. Charitable fantasies support ,wellbeing” and life itself. These ,good fantasies” have left the melancholic. His body, having these pro-health fantasies left, becomes empty, i.e. the melancholic becomes an empty tomb of its Self.

\section{Origin and Beginnings}

For Nietzsche and Foucault, the image of the source is a false image. The origin is a multitude of disturbances and uncertain entries. The premise of genealogy is not to search for the origin (Ursprung), but to either study the genesis or the emergence of the event (Enstehung) or its decent (Herkunft). Genealogy does not pretend to go back in time to restore an unbroken continuity that operates beyond the dispersion of forgotten things. Its duty is 
not to demonstrate that the past actively exists in the present, that it continue s secretly to animate the present, having imposed a predetermined form on all its vicissitudes. The search for descent is not the erecting of foundations: on the contrary, it disturbs what was previously considered immobile; it fragments what was thought unified; it shows the heterogeneity of what was imagined consistent with itself (Foucault, 1977).

Walter Benjamin in the The Origin of German Tragic Drama wrote: „Origin [Ursprung], although an entirely historical category, has, nevertheless, nothing to do with genesis [Entstehung]. The term origin is not intended to describe the process by which the existent came into being, but rather to describe that which emerges from the process of becoming and disappearance. Origin is an eddy in the stream of becoming, and in its current it swallows the material involved in the process of genesis. That which is original is never revealed in the naked and manifest existence of the factual; its rhythm is apparent only to a dual insight. On the one hand it needs to be recognized as a process of restoration and reestablishment, but, on the other hand, and precisely because of this, as something imperfect and incomplete. There takes place in every original phenomenon a determination of the form in which an idea will constantly confront the historical world, until it is revealed fulfilled, in the totality of its history. Origin is not, therefore, discovered by the examination of actual findings, but it is related to their history and their subsequent development" (Benjamin, 1977, p. 46). The category of origin is neither historical nor it is logical; origin is not isolated from the background constituted by statements of facts, but it concerns pre- and post-history. The origin is therefore in a swirl. The origin is a plurality of processes of becoming. Does Mira Marcinów's book deal with such a swirl and such a plurality of processes to becoming ,melancholy”?

The author seemingly follows medical discourse within the bounds of the clinic: diagnosis, nosology and therapy. Of course, the medical discourse must always address what it is dealing with, where it comes from, and how to bring an end to it. That is why The History of Polish Madness presents us with extensive diagnostics spanning the nineteenth century; the insane is obsessively brooding over his littleness (Raps), falls ill to ,, sympathetic nerve disease, the cause of his tormented melancholy writings" (Łowicki, 1846, pp. 85-96), or has insanity brought upon him due to multiple reasons (Ostafin), or yet, insanity may be unpredictable as in a case when a man accuses his wife of betrayal or refuses to recognize his paternity. Similarly, the therapies of melancholics follow in that many directions as many there are the diagnoses - one needs to travel to other countries, one needs to return home, one needs to keep on writing so that his black bile gets absorbed by ink, one needs to undergo electroconvulsive shock therapy, occasionally cold showers are necessary, occasionally a conversation, or loneliness is necessary. Perhaps the breakthrough in this diagnostic fever is a book published in Kraków by Krzyżanowski Publishing House in 1900, by Mieczysław Nartowski entitled Zaduma: Melancholia („Brooding: Melancholia”) the first Polish scientific monograph devoted entirely to melancholia. 
We have to remember that the author draws inspiration from the work of both a philosopher of science-Ian Hacking, in particular from his famous book Mad Travelers: Reflections on the Reality of Transient Mental Illness (Hacking, 1998), an archaeologist and genealogist of knowledge-Michel Foucault, albeit not so much from the History of Madness in the Classical Age (Foucault, 1961) or Mental Illness and Psychology (Foucault, 1954/1976), but his lectures on life and norms, i.e. The Birth of Biopolitics (2004). Finally, we come across more than a mention - authentic use - of the work of Arthur Oncken Lovejoy The Great Chain of Being: A Study of the History of an Idea (Lovejoy, 1939). We have here, therefore, a blend of many attempts to create the history of concepts, the history of ideas, the history of thought, intellectual history, cultural history, in a word: a multiple „history of multiplicity.”

\section{Speech of Melancholy and Speech about Melancholy}

For the author, however, the stake is neither politics without concepts nor an idea without politics. Mira Marcinów's book is a book about the birth of the „language of madness." Language is probably the most fascinating element of this huge encyclopaedia. Everything begins with mythology and literature, which had a monopoly on madness and the words for madness long before medicine. The author reminds us that in the mythology of the Slavs, „going mad" had its equivalent in the Polish word „owileć”-getting possessed by „vila”a woodland fairy or nymph the name of which was derived from Indo-European root meaning ,divinity” but also ,rave,” „wild," or „,rage.” It was in Juliusz Słowacki’s Kordian: First Part of a Trilogy: The Coronation Plot (1834) where Doctor invites our protagonist to go overtly mad: ,Just think of ways to stop yourself from thinking. Go mad and be a saint in Istanbul" (Słowacki, 1834/2010). Notably, this dervish motif associates madness with a holy madness. The main characters of Mira Marcinów's book-pioneers of Polish medicine and psychiatry of the nineteenth century, are all looking for a language of madness. Where do they find it? This is not a projective search, it is not coming up with new concepts or a new medical dictionary, it is not even re-thinking concepts or their new casting, but rather borrowing and annexing words and concepts found in colloquial language.

Colloquial expressions for madness come in aplenty. Melancholia is, therefore, man-fever (Pol. „chłopodur”), demon-mania (Pol. „demonomania”), daftness (Pol. „durnica”), gloominess (Pol. ,posępnica”), „dissimulation of specters," „despondency of the spirit," „loathing for life.” Ludwik Perzyna calls melancholia a feverish-sadness (Pol. „smutnodur”), Stanisław Chomętowski refers to it as melancholic craze (Pol. „szał melancholijny”), Leon Blumenstok calls it a paroxysm of trepidation (Pol. „napad trwogi”), and Kazimierz Kralczyński describes it as a rush of pensiveness (Pol. „napad zadumy”). The key and seemingly important for the author concept of ,gloominess” was introduced into Polish language by Bartłomiej Frydrych, in a direct translation of the French notion of lypémanie. What follows this standardized colloquial side of the language is the work of Klemens Malaszewski Analysis of another corpse (Rozbiór innego trupa, 1846), introduction of Stanisław Chomętkowski's concept melancholia catalepitica, Karl Ludwik's 
„depression of will,” and Antoni Hieronim Munkiewicz's „language of a morose,” to end with a reference to Alexander Niewiarowski's Manuscript of my cousin, a madman (Rękopis mego kuzyna wariata, 1853). The struggle for language is not only the struggle for a diagnosis, a dictionary that would allow both patients and doctors to describe the phenomenon of melancholia, it is above all the struggle for tools or for machine tooling of the Polish way of fabricating madness. Words are never innocent. Words are used for blaming and are themselves the cause of many blames. The battle of discourses does not take place at the patient's bed, nor even at the hospital, but in the court where averment of a madman confronts that of forensic medic.

The privileged position that the language of law holds results from two negations. The ,patient's bed" is itself an integral territory of melancholy, the place from which the disease has emerged, whereas the hospital is an artificial place in which melancholy may lose both its sovereign language and its face. The courtroom and the spectacle of generating a court judgment give the impression of a neutral place, in which the "language of melancholy” and „language about melancholy” can confront each other. However, such confrontation does not entail their unification, let alone reconciliation or mutual recognition. The language of law formulates verdicts, not diagnoses nor confessions. Madness in the book of Marcin Marcinów stands before the law and situates itself in the face of the language of law.

The question, however, is whether even a plethora of words describing madness can ever make up for something more, whether it helps to disclose the assembly line of Polish madness. Should it be otherwise, these obsolete words are at best simply inert, suspended, or disordered. If the battle for Polish madness is a battle of words and for words, then one should ask the author how the Polish madness is produced and fabricated. How does the author perceive this ,assembly line” of Polish madness or does the author even consider it at all? What, indeed, is the factory for producing Polish madness? It would seem that the author recognizes a certain ,reality of madness," which becomes the subject of her description, like any other ,object” in the world. There are, however, certain limits of constructivism in this book, which from the outset, falsely, admits to constructivism. For Mira Marcinów madness and its meaning are not so much described or fabricated here, as they are negotiated. However, if negotiated, then between whom? What are the rules for negotiating Polish madness? Is Polish madness negotiated at the Polish psychiatric ,,round table”?

The simplest of answers would be that a round table connects doctors and melancholics. The author operates on two sets - that of great Polish nineteenth-century clinicians-writers and that of melancholics-madmen who either on the stage of the hospital or in the intimate scene of their home recreate the drama of Polish madness. One should compare these two sets, describing them in detail and considering what are the conditions for these two sets to meet, if they meet at all. Who is here talking to whom? What language does a madman speak, and what language does the doctor use? Does the doctor speak the language of a madman? Or is it that the madman speaks the language of the doctor? Who is being quoted here? Or maybe both are using some „third party language,” for example, language remaining in the service of literature or religion? 
I therefore return to my intuition telling me that we do not have a uniform concept of melancholia. The word „melancholia” deludes us only with its single number. While the author seems to be aware of it, does she use this knowledge? For me, it is not a reliable hypothesis to assume that in this work Mira Marcinów fulfils herself as a historian of ideas, an archaeologist of concepts or a genealogist of knowledge - knowledge whispered before „institutional knowledge.” Bartłomiej Frydrych, whom the author seems to revere, says that the way to recognise a patient is in ,their thoughts and feelings are always exaggerated and confused, the simplest situations are considered very important and the conclusions drawn from these are the saddest. They are afraid of the faintest rustling, and they are disturbed by complete silence." To know madness of the patient is to learn about the exaggeration in thinking and feeling, in speaking and acting. Madness is an exaggeration. Madness is often also a façade. The façade of what? It is the facade for the lack of authentic thoughts, or, sometimes, any thoughts at all.

\section{Poland: A Place, Language, Nation}

The great problem of Mira Marcinów's work is that there is no such thing as Polish madness. All there is are plural Polish madnesses. Plurality is necessary here. The real problem and the bane of this work is that there is also no such thing as Polish psychiatry. Władyslaw Biegański writes that if Polish medicine disappeared it would make no dent in the nineteenth century world medicine (Biegański, 1896). There is no Poland, hence there is no Polish medicine. All these learned people, mentioned by the author, assimilated medical science in German or French. The problem is the lack of language. Lack of language can be even more annoying than the lack of an image.

Mira Marcinów's book is thus suspended between the vision of melancholia from Saturn and Melancholy by Raymond Klibansky, Erwin Panofsky and Fritz Sax, where the bust of all mourning is Albrecht Dürer's 1514 engraving Melencolia I, and the twentieth century Peter Kramer's attempt to reduce melancholia to depression, epitomizing the era of cosmetic psychopharmacology (Klibansky, Panofsky, Saxl, 1964). Somewhere between these two poles we find a Renaissance monograph about black bile-Marsilio Ficino's Three Books on Life and Robert Burtons The Anatomy of Melancholy. It seems valid a question to ask who is the melancholic suspended between these two poles? What is the subject in this long run to „becoming melancholia”? Where does the melancholic come from? Does the melancholic come from Poland?

Melancholics come from a planet whose quality is sadness - Saturn. Saturn, on the one hand, named after the Roman god of agriculture, is a planet that is as heavy as the earthly vale, cold and dry, and produces only material people who are fit for farming. This quality indeed corresponds to Poland. On the other hand, Saturn, the highest of planets, produces highly spiritual beings who tend to shy away from the earthly life and whose fulfilment is in constant deepening of their spirituality. The latter quality, in turn, is in no way reminiscent of Poland. Setting Poland aside, we are allowed to conclusively determine the 
melancholic to be an extreme subject. Saturn itself is a planet of extremity. Melancholia is extremitas. Saturn is a demon of opposites, it brings upon the souls inertia and dullness, but also an immensity of intelligence and contemplation. The melancholic is associated with Kronos, Kronos who is impotent and yet he spawns, it is an absolute monster sporting the highest intellect. Melancholia is a monstrosity spawning impotence.

Has melancholia ever had its glory days? Today, these are the days of glory for psychosis and depression, melancholia does not even begin to come close. Melancholy paradoxically found itself most comfortable in the Renaissance, not the Baroque. The Renaissance appears to the Baroque not as a non-religious, pagan epoch, but as a moment of secular freedom in the lives of believers. Medicine from Salerno, and in particular Constantine the African, provides a straightforward answer to the question: who is a melancholic? It is a dry and cold subject, jealous and dismal, greedy, possessive, unfaithful, shy, and with earthy complexion. Melancholy is insatiable in thinking, yet this thinking is submerged in finitude and curled up as a scroll. Melancholic inscribes the infinity of thinking into the finiteness and the closed space of secular cosmos.

Melancholic writes its words with black bile. The black bile that spills out from the spleen is poisoning. The melancholic is thus afflicted with acedia, or „tszczyca”-carefree indifference to life, sourness and blemish. Blemish, on the other hand, becomes a sublimation, it becomes another health and another life - albeit more etherical. Melancholy is hyperesthesia, hypersensitivity, hyper-life, but it is also an infinite indifference towards the affairs of earthly life. Melancholy is also the inability to experience intensity and loss of affect, but it is also hyper-affectivity, hyper-reactiveness. Melancholy never ceases to amaze as a violent rejection of the boredom of life for another, more extreme life.

It brings us back to the problem of the language of madness. The language of madness is always the language of a generalized state of emergency. This language is subject to the antinomy of reification and over-determination. Reification of the language means that it is devoid of subjectivity. In melancholic speech it is the things which speak and things alone; it is a strictly objectified language that is supposed to fill the subject's apparent emptiness, after the annihilation of all objects of love, and after the annihilation of the Self. Likewise, its over-determination means that the meaning of each expression is determined by more than one element, and in principle it is always in the transition between the breakdown of one object and the birth of a new one.

Anything, a person or a relationship can always mean the opposite. The language of melancholy is not a mere convention of expression, but it is the expression of termination of all convention, that is, denunciation of all authority. The language of melancholy becomes a rubble, for it has ceased to serve the purpose of communication and as a newborn ,object" it ex-poses its dignity before the dignity of gods and kings. The language of the melancholic is rich in material. Perhaps the language has never been less winged, because the weight of metaphors makes it now impossible to fly or sail. This language finds is fulfilment merely in sound or language gestures. The split between a meaningful image of the concept and the stunning sound of a word forces the melancholic to look into the ,language 
of things." There, however, he finds only the evil infinity. Melancholy always exalts the art of sound over the depth of meaning. Speech of the melancholic is ultra-sensual and fragmented to the state of pure debris. The crumbling of speech is a funeral song, a lamentation of the melancholic. Freud writes that lamentations (Klagen) of melancholy are also accusations (Anklagen). The language of melancholy is being constantly shaken with the eruptions of its rebellious elements (Freud, 1917).

The question then is whether madness is lived within the language and the language itself is an abyss of chaos, or, on the contrary, language is the only barrier against madness and allows one to walk over the abyss. Martin Heidegger perfectly diagnoses this problem when he writes that in speaking we walk on a light suspension footbridge balancing over the abyss. Things reify and captivate mortals renouncing them. The naming God of the world is nothing but a fugue of tear. However, this tearing is a pain. The way language always speaks is "the ringing of silence," and everyday speech is a forgotten and used poem. Madness (Wahnsinn) does not imply absurdity of thinking. „The word Wahn (delusion, error) belongs to the old German wana and means: 'without' (ohne). Madman thinks (sinnt), thinks like no other except him. At the same time, he remains deprived of the senses of others. Himself, he has a different sense. Sinnan means originally: to travel, to go towards ..., to take direction; the Indo-Germanic root sent and set means "the way", (Heidegger, 1982, p. 41). Melancholic thinks, and he does so either as an prematurely deceased subject or a never born subject.

\section{Number: The Face and Faces of Melancholy}

Although Mira Marcinów knows all this she is mysteriously silent about it. She writes in Polish about Poland, which — as a matter of fact — does even not exist. The poverty of Polish melancholy stands in stark contrast to the affluence of the German Baroque melancholy or the Italian melancholy of Dante's times. It brings us back to Poland and the Polish language. What Mira Marcinów presents us with, in addition to the collection of Polish scholars and „Poland of psychiatrists,” a collection of male and female melancholic. In The History of Polish Madness, we find the cases of ,people in their reveries” in Poland, something that the author calls a ,melancholy syntax."

Thus we find a collection of Polish female melancholics-Dorota S, Joanna O, and Kunegunda J. who was diagnosed by Frydrych in 1845. This collection begins to grow to a level comparable to Freud's and Breuer's famous collection of hysterics from their study of hysteria (Breuer, Freud, 1895/1955). Mira Marcinów does not try to describe these cases in terms of gender or even feminism or psychoanalysis, although her account certainly introduced a feminine version of melancholy. Maciej Lowicki, serving here as the Polish anticipation of Julia Kristeva, describes two types of melancholy - thoraco-abdominal and solely abdominal (Kristeva, 1989). The same doctor is the first to write about „genitality of female melancholics” and testifies that „sub-abdominal melancholics” have „inclination to lust.” Mira Marcinów describes this series of female melancholies in terms 
of everyday misery of life. It is a great value of this work that it uses everyday language to describe everyday melancholy. Mira Marcinów not so much trivializes Polish melancholy, but rather reads it at the ,zero level,” at the „level of the earth,” at the level of Polish soil, without succumbing to the illusion of depth.

There also follows a collection of male melancholics. Ignacy Mazurkiewicz is the most interesting case in this collection - a mad criminal who is known for writing a letter to the priest about killing or hurting his father. It opens debate similar to the French debate around the famous text „I, Pierre Riviére, having slaughtered my mother, my sister, and my brother” (Foucault, 1975) with a foreword by Michel Foucault. Polish psychiatry and Polish judiciary, resorting to the intellect of Kazimierz Kralczyński, poses a question about the rationality of madness, that is, the question: why did Ignacy Mazurkiewicz kill his father? The murderer himself answers briefly and pragmatically — his father had problems with digestion, he was grim, obese, he had bad blood, and he did not allow anybody be happy. Polish madness is within reason, not from beyond reason. Poles are mad for reason, not against it.

What I truly miss in the book is more data on Polish melancholics. What I truly miss is an index or an album of Polish melancholics. I would like to know them closer, I would like to see their portraits and look into their faces, I would like to know about their age, their lives, their dreams, their work, their maturation, and their family histories. I would like to know when and due to what reasons they lost interest in life. I would like to make sure whether they all come from Saturn, this dry and cold planet. Finally, I would like ascertain whether Saturn is akin to Poland. Unfortunately, The History of Polish Madness does not provide all that as it falls victim to the lack of archaeological data, scarcity of the source material, and - at the same time - the syndrome of ,,archive fever.” Mira Marcinów presents us with an image of but one constellation, that of singular madness. I find not a glimpse of sun on this Polish soil in the black sky of melancholy.

In conclusion, the strength of Mira Marcinów's book is that it poses disturbing questions rather than provides easy answers. First and foremost, in the course of reading this book it becomes apparent that it is not clear how to develop the epistemological history of melancholy - understood as a scientific idea seeking coherence and adequacy with the language of medicine, and political history of melancholy - understood as a symptom of a given cultural context, material or political, in this case regarding Poland. Science creates or assembles concepts, but it assembles them always in a specific place and time.

Secondly, we do not know how to distinguish the very language of melancholy, which is the language of the state of emergency, from the language of medicine, which is the language of description of a certain medical disorder. Medicine to a greater extent than we think refers to normality than to the problematic concept of health. Medicine, while managing human life, adopts a normative attitude, which does not amount to providing advice on how to live wisely, but allows to influence the whole of physical and moral relationships connecting the individual with the society. 
Thirdly, it seems that the very concept of melancholy remains mobile and fluid. The proposed ,erotic constellation of melancholy” suggests that the melancholic subject loses the ability to find new objects of love. This incapacity condemns it, at the same time, to open nihilism, which is not only the ,nothingness of the will," nor the ordinary ,will of nothingness," but above all the discovery of the nothingness of knowledge and the futility of the process of cognition. Inability to find objects worth love is at the same time an inability to find objects worth the effort of knowing. The reasons for melancholy, from this point of view, go beyond the trivial case of loss and include all resentments, rejections, failures, disappointments, including disappointments related to the process of cognition. Melancholy brings the subject to ruin. In this sense, melancholy would be the limit of all medical knowledge, declaring that in clinical cognition there is no mystery of ,disorder," that there is no secret of madness, and that there is nothingness of the very cognition of madness. Madness is the recognition of nothingness of the world.

\section{References}

Benjamin, W. (1977). The Origin of German Tragic Drama. (J. Osborne, Trans.). London, UK: New Left Books.

Benjamin, W. (2005). On the Concept of History. (C. Turner, Trans.). London, UK: Verso.

Biegański, W. (1896). Medycyna i filozofia: Uwagi z powodu dzieła prof. H. Struvego, pt. „Wstęp krytyczny do filozofii" [Medicine and Philosophy: Comments Due to the Work of prof. H. Struve, entitled „Critical Introduction to Philosophy”], Medycyna, 31(24), 31-33.

Breuer, J., \& Freud, S. (1955). Studies on Hysteria. (J. Strachey, Trans.). In The Standard Edition of the Complete Psychological Works of Sigmund Freud (Vol. 2). London, UK: Hogarth Press. (Original work published 1895)

Derrida, J. (1978). Cogito and the History of Madness. In J. Derrida, Writing and Difference. (A. Bass, Trans.). London, UK: Routledge.

Didi-Huberman, G. (2003). Invention of Hysteria: Charcot and the Photographic Iconography of the Salpetrière. (A. Hartz, Trans.). London, UK: The MIT Press.

Foucault, M. (1977). Nietzsche, Genealogy, History. In D. F. Bouchard (Ed.), Language, CounterMemory, Practice: Selected Essays and Interviews. Ithaca: Cornell University Press. (Original work published 1971)

Foucault, M. (1965). Madness and Civilization: A History of Insanity in the Age of Reason. (R. Howard, Trans.). New York, NY: Random House.

Foucault, M. (1997). Madness, the Absence of Work (d'œuvre). In A. I. Davidson (Ed.), Foucault and his Interlocutors. Chicago, IL: Chicago University Press.

Foucault, M. (Ed.). (1975). „I, Pierre Riviére, having slaughtered my mother, my sister, and my brother": A Case of Parricide in the 19 $9^{\text {th }}$ Century. (F. Jellinek, Trans.), New York, NY: Pantheon Books. 
Foucault, M., (1976). Mental Illness and Psychology. (A. M. Sheridan-Smith, Trans.). New York, NY: Harper and Row. (Original work published 1954)

Freud, S. (1917). Mourning and Melancholia (J. Strachey, Trans.). In The Standard Edition of the Complete Psychological Works of Sigmund Freud, Volume XIV (1914-1916): On the History of the Psycho-Analytic Movement, Papers on Metapsychology and Other Works (pp. 237-258), London, UK: Hogarth.

Hacking, I. (1998). Mad Travelers: Reflections on the Reality of Transient Mental Illness. Charlottesville, VA: University of Virginia Press.

Heidegger, M. (1982). On the Way to Language. (P. D. Hertz, J. Strambaugh, Trans.). New York, NY: Harper \& Row.

Klibansky, R., Panofsky, E., \& Saxl, F. (1964). Saturn and Melancholy: Studies in the History of Natural Philosophy, Religion, and Art. New York, NY: Basic Books.

Kristeva, J. (1989) Black Sun: Depression and Melancholia. (L. S. Roudiez, Trans.), New York, NY: Columbia University Press.

Lovejoy, O. A. (1936). The Great Chain of Being: A Study of the History of an Idea. Cambridge, MA: Harvard University Press.

Łowicki, M. (1846). Melancholia [Melancholia], Przeglad Naukowy, 5(3), 85-96.

Marcinów, M. (2018). Historia polskiego szaleństwa. Tom I. Stońce wśród czarnego nieba. Studium melancholii [The History of Polish Madness. Vol.1. The Study of Melancholy], Gdańsk, Poland: Słowo/obraz terytoria.

Nietzsche, F. (1995) The Use and Abuse of History (R. T. Grey, Trans.). In Friedrich Nietzsche, Unfashionable Observations. Stanford, CA: Stanford University Press. (Original work published 1878)

Słowacki, J. (2010). Kordian. (G. T. Kapolka, Trans.). Chicago, IL: Green Lantern Press. (Original work published 1834)

The editorial and publishing process of this publication has been financed by the Ministry of Science and Higher Education from the funds for the dissemination of research (DUN) within the framework of publishing activity, contract no. 711/P-DUN/2019, period of implementation: the years 2019-2020. 